\title{
PENERAPAN LEAN MANUFACTURING UNTUK MEMINIMASI WASTE WAITING TIME PADA PROSES PRODUKSI SPRING GUIDE XXX DI CV. GRADIENT
}

\section{APPLICATION OF LEAN MANUFACTURING FOR MINIMIZING WASTE WAITING TIME IN THE PRODUCTION PROCESS OF SPRING GUIDE XXX AT CV. GRADIENT}

\author{
Kuntari Puspa Sari ${ }^{1}$, Agus Alex Yanuar $^{2}$, Meldi Rendra ${ }^{3}$ \\ 1,2,3Program Studi Teknik Industri, Fakultas Rekayasa Industri, Telkom University \\ ${ }^{1}$ kuntaripuspasari@student.telkomuniversity.ac.id ${ }^{2}$ axytifri@telkomuniversity.ac.id ${ }^{3}$ meldirendra@telkomuniversity.ac.id
}

\begin{abstract}
Abstrak- CV. Gradient merupakan perusahaan manufaktur yang memproduksi plastik menggunakan mesin injection molding. Produk pada penelitian ini fokus pada produk spring guide dengan tipe $X X X$. Berdasarkan hasil observasi, wawancara dan kuesioner terdapat beberapa waste yang ditemukan dalam proses produksinya, salah satunya adalah waste yang menjadi fokus penelitian yaitu waste waiting time. Metode untuk meminimasi waste tersebut adalah dengan menggunakan konsep lean manufacturing. Penelitian dimulai dengan melakukan observasi dan wawancara untuk memperoleh data-data yang menunjang pemetaan proses produksi spring guide yang terjadi dengan menggunakan value stream mapping (VSM) dan process activity mapping (PAM) sehingga diketahui total waktu non-value added akibat waste waiting time adalah 7161.87 detik atau $57.8 \%$ dari lead time. Setelah itu, dilakukan analisis akar penyebab waste waiting time dengan menggunakan 5 whys dan fishbone diagram. Hasil dari analisis akar penyebab waste dapat digunakan untuk menentukan usulan rancangan yang akan dibuat berupa jadwal pemeliharaan mesin injection molding menggunakan preventive maintenance untuk mengurangi aktivitas non-value added. Pada kondisi yang akan datang, usulan rancangan dapat menghilangkan waktu menunggu dan waktu perbaikan yang menyebabkan waste waiting time Berdasarkan future state total waktu non-value added dapat dikurangi menjadi 721.87 detik atau $12.12 \%$ dari lead time yang diperoleh dari penghilangan aktivitas menunggu dan aktivitas perbaikan.
\end{abstract}

Kata kunci : Lean manufacturing, waste waiting time, value stream mapping, process activity mapping, fishbone, preventive maintenance

Abstract- CV. Gradient is a manufacturing company that produces plastic using injection molding machine. Products on this research focus on spring guide with type XXX. Based on the results of observation, interview and questionnaire there are some waste found in the production process, one of the waste in this research is focus on waste waiting time. Methods to

$\begin{array}{ll}\text { Sejarah artikel } & \\ \text { Diterima redaksi: } & : 00 \text { Februari } 00 \\ \text { Revisi akhir } & : 00 \text { Maret } 00 \\ \text { Diterbitkan online } & : 00 \text { April } 00\end{array}$

minimize that waste is using the concept of lean manufacturing. The research begins by doing observations and interviews to obtain data for mapping spring guide production process with value stream mapping (VSM) and process activity mapping (PAM), so the total time of non-value added because of waste waiting time is 7161.87 seconds or $57.8 \%$ of lead time. After that, the analysis of the root causes of waste waiting time defined by using 5 whys and fishbone diagram. The results of the analysis on the root causes by waste can be used to determine the design of the proposals to be made in the form of schedule maintenance of the injection molding machine using the method of preventive maintenance to reduce non-value added activity. The application of the proposed design can eliminate the waiting time and time to repair that causes of waste waiting time. Future state based on total time of non-value added is 721.87 or at $12 \%$ of lead time and retrieved from the removal of waiting activities and repair activities.

Keywords : Lean manufacturing, waste waiting time, value stream mapping, process activity mapping, fishbone, preventive maintenance

\section{PENDAHULUAN}

Fungsi produksi secara umum berfungsi untuk mentransformasikan input menjadi output dengan ketetapan kualitas yang telah ditetapkan oleh pihak manajemen perusahaan yang sesuai dengan keinginan pelanggan. Oleh karena itu, diperlukan suatu peningkatan dan perbaikan kualitas secara terus menerus agar dapat menghilangkan pemborosan atau waste dalam suatu proses produksi dengan pendekatan lean manufacturing. Lean Manufacturing merupakan konsep pendekatan yang berorientasi dalam mengeliminasi waste yang terjadi dalam sistem produksi[1].

CV. Gradient merupakan perusahaan dalam bidang manufaktur yang salah satu produknya adalah plastik spring guide tipe $X X X$ yang memiliki pesanan dengan jumlah produksinya dapat mencapai 500 ribu - 1 juta pieces per bulan seperti yang ditampilkan pada Tabel I. 
TABEL I

TOTAL PRODUKSIDAN REALISASI PRODUKSI PERIODE JANUARI-NOVEMBER 2016

\begin{tabular}{ccccc}
\hline Bulan & $\begin{array}{c}\text { Total } \\
\text { Permintaan }\end{array}$ & $\begin{array}{c}\text { Realiasasi } \\
\text { Produk }\end{array}$ & $\begin{array}{c}\text { Gap } \\
\text { Produksi } \\
(\text { Pcs })\end{array}$ & $\begin{array}{c}\text { \% Ketercapaian } \\
\text { Produksi }\end{array}$ \\
\hline Januari & 248000 & 248000 & 0 & $100.00 \%$ \\
Februari & 354300 & 350100 & -4200 & $98.81 \%$ \\
Maret & 427600 & 382600 & -45000 & $89.48 \%$ \\
April & 404400 & 382600 & -21800 & $94.61 \%$ \\
Mei & 424000 & 420400 & -3600 & $99.15 \%$ \\
Juni & 448000 & 448000 & 0 & $100.00 \%$ \\
Juli & 378000 & 349000 & -29000 & $92.33 \%$ \\
Agustus & 406000 & 264900 & -141100 & $65.25 \%$ \\
September & 400000 & 400000 & 0 & $100.00 \%$ \\
Oktober & 392000 & 376700 & -15300 & $96.10 \%$ \\
November & 376000 & 341400 & -34600 & $90.80 \%$ \\
\hline
\end{tabular}

Berdasarkan Tabel I dapat dilihat bahwa total produksi spring guide $X X X$ belum dapat memenuhi target produksi berdasarkan permintaan hampir setiap bulannya yang disebabkan oleh beberapa faktor yang menghambat jalannya proses produksi seperti telah terjadi waste atau pemborosan pada proses produksi yang berlangsung di perusahaan. Untuk mengetahui jenis-jenis waste yang terdapat pada proses produksi spring guide $X X X$ dapat diketahui dengan mengidentifikasi melalui analisis persoalan waste hasil observasi yang kemudian hasilnya dibandingkan dengan hasil kuesioner yang disebar kepada responden yang mengerti tentang proses produksi yang terjadi. Tabel II adalah hasil dari pengolahan kuesioner untuk mengidentifikasi waste

TABEL II

PRESENTASE WASTE HASIL KUESIONER

\begin{tabular}{ccc}
\hline No & Waste & Persentase Waste \\
\hline 1 & Defects & $22 \%$ \\
2 & Motion & $21 \%$ \\
3 & Waiting time & $21 \%$ \\
4 & Inventories & $11 \%$ \\
5 & Overproduction & $9 \%$ \\
6 & Transportation & $9 \%$ \\
7 & Process & $6 \%$ \\
\hline
\end{tabular}

Berdasarkan Tabel II dapat dilihat bahwa hasil persoalan kuesioner menunjukkan adanya identifikasi waste dengan waste dominan yaitu waste defect, waste waiting time, dan waste motion yang hasil tersebut sama dengan hasil observasi langsung pada lantai produksi. Pada penelitian ini akan difokuskan untuk meminimasi waste waiting time. Waste waiting time adalah jenis pemborosan yang terjadi karena menunggu. Waste ini dapat dilihat dari keterlambatan yang tampak melalui orang-orang yang sedang menunggu mesin, peralatan, bahan baku, perawatan/pemeliharaan (maintenance), atau mesin-mesin yang sedang menunggu perawatan, orang-orang, bahan baku, peralatan, dan lain-lain[2]. Berdasarkan hasil observasi langsung dan wawancara dengan bagian poduksi, terdapat dua penyebab tejadinya pemborosan waiting time pada saat proses produksi berlangsung. Penyebab pertama yaitu adanya waktu tunggu perbaikan karena mesin mengalami kerusakan saat proses produksi berlangsung yang disebabkan oleh adanya beberapa part dalam mesin yang bermasalah, seperti peer yang digunakan sebagai pemberi tekanan (pendorong) untuk membuka dan menutup molding bermasalah. Penyebab kedua yaitu adanya waktu tunggu bahan baku karena operator mengerjakan pekerjaan lain seperti membantu operator lain dalam melakukan perbaikan mesin atau melakukan pekerjaan lain yang seharusnya tidak dilakukan.

Oleh karena itu, gambaran solusi yang akan diusulkan peneliti dalam rangka meminimasi waste waiting time berupa persoalan waktu tunggu karena mesin error atau mengalami kerusakan dan waktu tunggu bahan baku karena operator mengerjakan pekerjaan lain yang bukan pekeraan seharusnya yaitu berupa usulan rancangan jadwal pemeliharaan mesin injection molding dengan menerapkan preventive maintenance.

\section{HASIL DAN ANALISIS}

Proses produksi spring guide diproduksi melalui beberapa proses yang mendukung berjalannya proses produksi yang memiliki aktivitas-aktivitas pada proses tersebut. Deskripsi kerja dan lantai produksi akan digambarkan melalui diagram SIPOC (Suplier, Input, Process, Output, Customer) yang digunakan untuk mengidentifikasi setiap elemen guna membantu menjelaskan ruang lingkup dari penelitian ditampilkan pada Gambar 1 .

\section{A. Value Stream Mapping Current State}

Value Stream Mapping merupakan tools yang menyajikan suatu metode visual untuk memetakan jalur produksi dari sebuah produk yang di dalamnya terdapat aliran material dan informasi yang bermanfaat dalam menyoroti pemborosan [3]. Perancangan Value Stream Mapping dilakukan dengan tujuan untuk menggambarkan proses yang terjadi pada aliran informasi dan aliran fisik agar dapat lebih memahami proses produksi spring guide $X X X$. Berdasarkan Gambar 2 dapat dilihat bahwa pada proses produksi spring guide XXX mempunyai lead time sebesar 12391.66 detik dan total nonvalue added time sebesar 1111.85 detik.

\section{B. Process Activity Mapping Current State}

Process activity mapping (PAM) adalah peta yang menggambarkan urutan dari proses, pemeriksaan, transportasi, menunggu dan penyimpanan yang terjadi selama proses produksi [4]. Process Activity Mapping digunakan untuk menjabarkan urutan proses produksi beserta aktivitasnya berdasarkan area atau lokasi produksi, mesin yang digunakan, lama waktu prosesnya, dan keterangan aktivitasnya. Pada Tabel III merupakan hasil dari perhitungan process activity mapping

TABEL III

HASIL PROCESS ACTIVITY MAPPING CURRENT STATE

\begin{tabular}{lc}
\hline \multicolumn{1}{c}{ Keterangan } & Waktu (detik) \\
\hline Lead Time & 12391.66 \\
Total Value Added Time & 1111.85 \\
$\%$ Value Added & 9.0 \\
Total Necessary Non-Value Added Time & 4121.05 \\
$\%$ Necessary Non-Value Added Time & 33.3 \\
Total Non Value Added Time & 7161.87 \\
$\%$ Non Value Added Time & 57.8 \\
\hline
\end{tabular}

Berdasarkan Tabel III dapat diketahui bahwa total non-value added time pada proses produksi spring guide mencapai $57.8 \%$ dari lead time yang disebabkan oleh adanya waste waiting time yaitu pada aktivitas waktu tunggu material dan menunggu perbaikan sparepart mesin injection molding. 
DOI: https://doi.org/10.25124/jrsi.v4i01.218

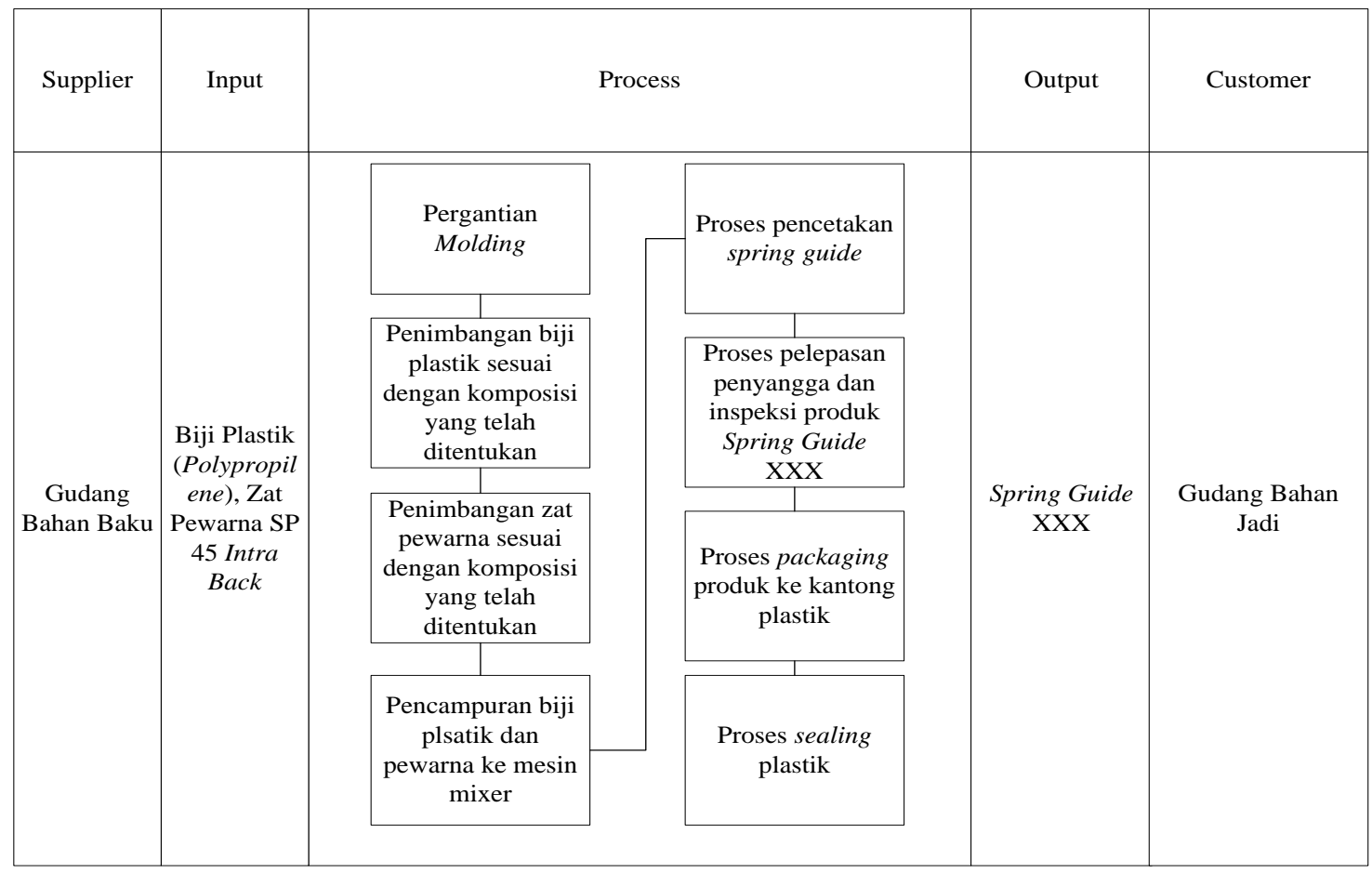

Gambar 1 Diagram SIPOC di CV. Gradient

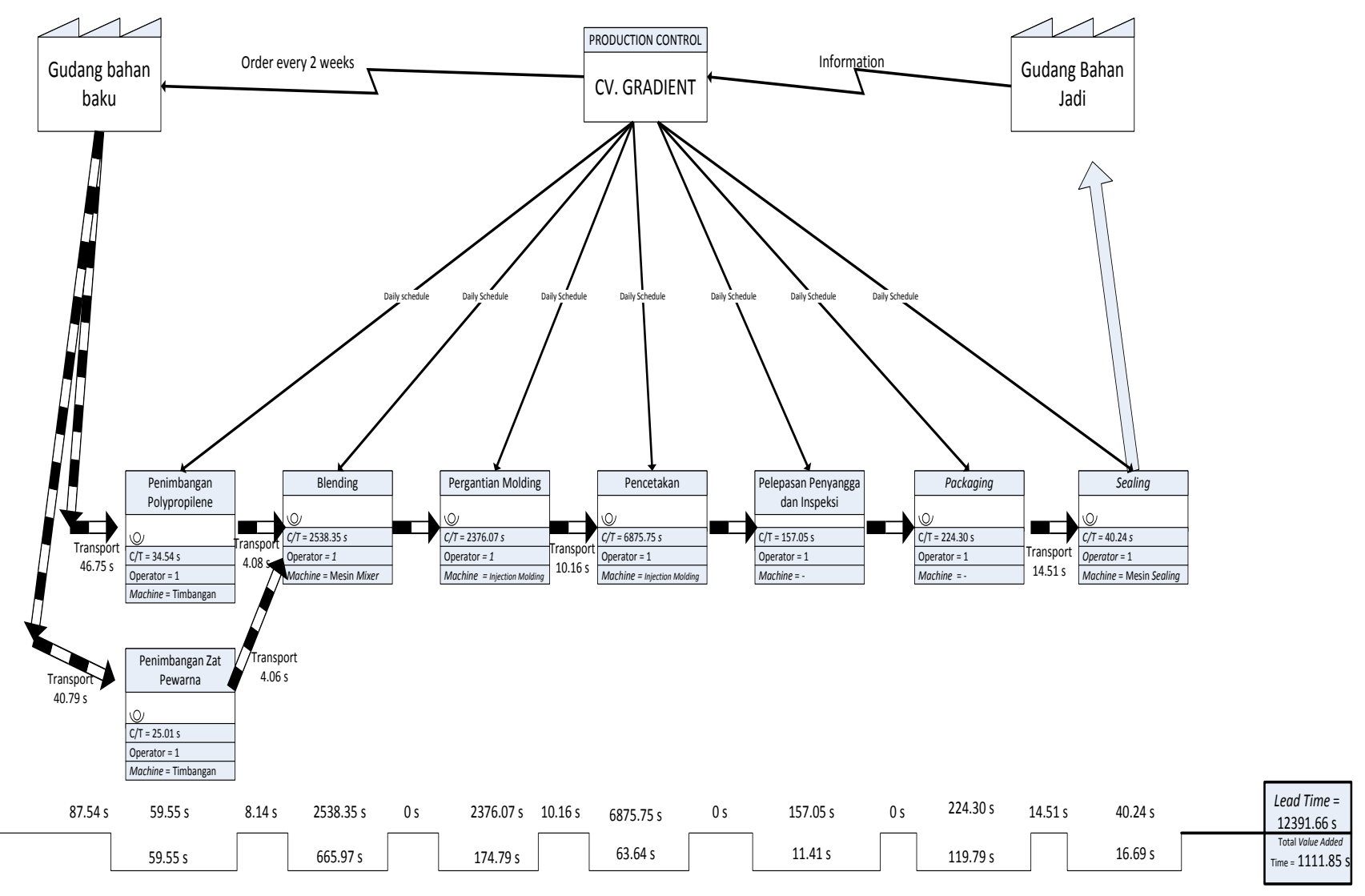

Gambar 2 Value stream mapping current state

Penerapan Lean Manufacturing untuk Meminimasi Waste Waiting Time pada Proses Produksi 


\section{Takt Time}

Takt time digunakan untuk mengetahui ukuran dari seberapa sering sebuah proses produksi harus memproduksi satu unit keluaran produksi yang menggunakan data demand suatu produk dalam perhitungannya[5]. Data yang digunakan adalah data demand dari produk spring guide XXX pada periode Januari 2016 - Desember 2016. Waktu efektif per hari dari produk spring guide XXX selama proses produksi berlangsung adalah 21 jam lebih 15 menit yang berarti 36900 detik per hari. Berikut ini adalah perhitungannya:

Takt time $=\frac{\text { Waktu efektif per hari }}{\text { Demand per hari }}=\frac{\mathbf{3 6 9 0 0}}{\mathbf{3 3 3}}=110,92$ detik

Berdasarkan perhitungan takt time diatas, didapatkan hasil takt time spring guide $X X X$ adalah sebesar 110,92 detik. Dengan demikian, dapat di analogikan bahwa setiap lantai produksi atau proses produksi harus dapat mengeluarkan 1 unit keluaran produksi dengan waktu 110,92 detik. Pada area pencampuran dan pencetakan memiliki waktu tertinggi dan melebihi takt time yang dapat menghambat waktu dari penyelesaian produk untuk sampai ke customer.

\section{Identifikasi Penyebab Waste Waiting Menggunakan Fishbone Diagram dan 5 Whys}

Dalam mengidentifikasi penyebab waste waiting time, dapat diketahui pada process activity mapping yaitu dengan melihat adanya aktivitas yang tidak memberikan nilai tambah seperti aktivitas menunggu. Oleh karena itu, dapat dilanjutkan dengan pencarian akar masalah untuk mengidentifikasi lebih lanjut menggunakan fishbone diagram seperti pada Gambar 3.

Berdasarkan hasil dari pemetaan fishbone diketahui bahwa terdapat dua faktor utama yang menyebabkan terjadinya waste waiting time pada proses produksi spring guide $X X X$ yaitu faktor metode dan mesin. Pada faktor metode terdapat kegiatan menunggu yang berkaitan dengan proses produksi spring guide $X X X$ yaitu adanya waktu menunggu material yang terjadi pada area pencampuran setelah dilakukannya pencampuran material dalam mesin mixer. Kegiatan menunggu yang terjadi karena faktor mesin (machine) yaitu adanya waktu menunggu perbaikan sparepart pada mesin injection molding untuk produk spring guide XXX.

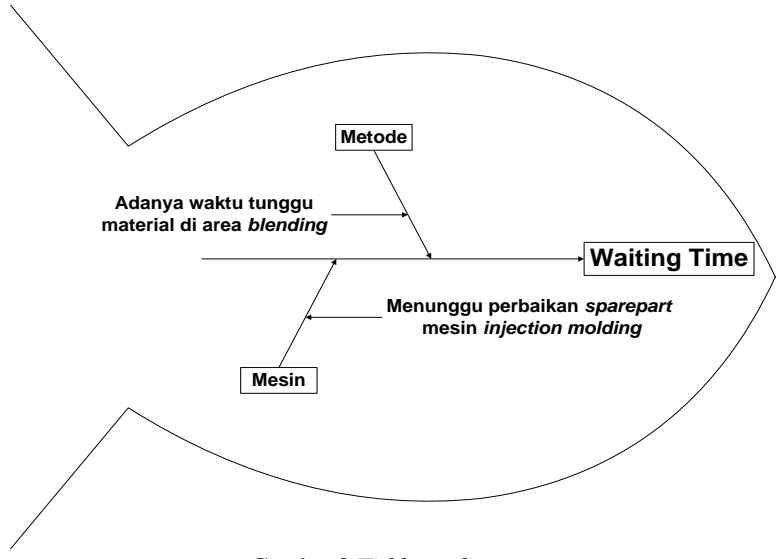

Gambar 3 Fishbone diagram
Setelah menemukan faktor dan penyebab masalah, lalu menggunakan 5 whys untuk mencari sumber permasalahan. 5 whys digunakan dengan cara mengulang pertanyaan "mengapa" sampai menemukan akar penyebab masalah yang dapat diperbaiki.

\section{E. Perancangan Usulan}

Usulan dirancang untuk mengatasi akar penyebab dari waiting time yang terjadi pada proses produksi spring guide $X X X$ yang telah diperoleh berdasarkan fishbone diagram dan analisis 5 whys.Usulan rancangan dari setiap akar penyebab masalahnya akan dijelaskan pada Tabel IV. Usulan rancangan utama untuk mengatasi akar penyebab masalah pada waste waiting time adalah dengan merancang jadwal pemeliharaan mesin injection molding karena perusahaan tidak menerapkan preventive maintenance dan tidak adanya jadwal pemeliharaan secara berkala.

TABEL IV

USULAN RANCANGAN

\begin{tabular}{|c|c|c|c|}
\hline Cause & Subcause & Akar Penyebab & Usulan \\
\hline Metode & $\begin{array}{l}\text { Adanya } \\
\text { waktu } \\
\text { tunggu } \\
\text { material di } \\
\text { area } \\
\text { blending }\end{array}$ & $\begin{array}{c}\text { Tidak ada } \\
\text { tindakan } \\
\text { preventive } \\
\text { maintenance oleh } \\
\text { perusahaan }\end{array}$ & $\begin{array}{l}\text { Pembuatan interval waktu } \\
\text { pemeliharaan mesin injection } \\
\text { molding selanjutnya dengan } \\
\text { preventive maintenance, }\end{array}$ \\
\hline Mesin & $\begin{array}{l}\text { Menunggu } \\
\text { perbaikan } \\
\text { sparepart } \\
\text { mesin } \\
\text { injection } \\
\text { molding }\end{array}$ & $\begin{array}{l}\text { Tidak ada jadwal } \\
\text { pemeliharaan } \\
\text { peer secara rutin } \\
\text { Tidak ada jadwal } \\
\text { pemeliharaan } \\
\text { cooling system } \\
\text { secara rutin } \\
\text { Tidak ada jadwal } \\
\text { pemeliharaan } \\
\text { nozzle secara } \\
\text { rutin } \\
\text { Tidak ada jadwal } \\
\text { pemeliharaan } \\
\text { untuk oil system } \\
\text { secara rutin }\end{array}$ & $\begin{array}{l}\text { Pembuatan jadwal } \\
\text { pemeliharaan pada sparepart } \\
\text { mesin injection molding, }\end{array}$ \\
\hline
\end{tabular}

Pembuatan jadwal pemeliharaan mesin dimulai dari menentukan interval waktu kerusakan mesin pada komponen cooling air, oli samping, nozzle, dan peer untuk meminimalisir terjadinya kerusakan mesin secara tiba-tiba. Penerapan tindakan preventive maintenance ini yaitu dapat mengetahui waktu optimal untuk penggantian komponen sebelum terjadinya kerusakan mesin [6]. Preventive Maintenance merupakan proses pemeliharaan yang terjadwal, terencana dan teratur untuk melakukan repair mesin dan peralatan kerja. Penjadwalan pemeliharaan semakin penting karena biaya pemeliharaan memiliki porsi yang signifikan terhadap tujuan dari penjadwalan pemeliharaan adalah untuk meningkatkan Mean Time To Failure (MTTF) dan atau mengurangi Mean Time To Repair (MTTR) [7].

Penentuan interval waktu dilakukan dengan bantuan software Minitab 15 dan AvSim+ 9.0. Manual book software. Tahap awal perhitungan pada komponen cooling system yaitu membuat interval waktu kerusakan mesin dengan melihat data waktu historis kerusakan mesin sebelumnya yang ditampilkan pada Tabel $\mathrm{V}$ dan kemudian dilakukan perhitungan menggunakan software minitab dan Avsim 
TABEL V

CATATAN HISTORIS KOMPONEN COOLING SYSTEM

\begin{tabular}{cccccc}
\hline \multicolumn{5}{c}{ Kerusakan } \\
\hline Tanggal & Mulai & Tanggal & Selesai & $\begin{array}{c}\text { TBF } \\
\text { (jam) }\end{array}$ & $\begin{array}{c}\text { TTR } \\
\text { (jam) }\end{array}$ \\
\hline 6-Apr-16 & $16: 10$ & 6-Apr-16 & $16: 40$ & & $0: 50$ \\
15-Apr-16 & $16: 30$ & 15-Apr-16 & $17: 00$ & 216.33 & $0: 50$ \\
10-Aug-16 & $9: 15$ & 10-Aug-16 & $10: 20$ & $2,800.75$ & $1: 08$ \\
10-Sep-16 & $15: 00$ & 10-Sep-16 & $15: 20$ & 749.75 & $0: 33$ \\
21-Nov-16 & $7: 00$ & 21-Nov-16 & $7: 30$ & $1,720.00$ & $0: 50$ \\
\hline
\end{tabular}

Setelah memperoleh data kerusakan mesin, selanjutnya melakukan perhitungan Uji Anderson Darling menggunakan software minitab untuk menentukan distribusi yang akan digunakan[8]. Berdasarkan Gambar 4 dan Gambar 5, distribusi yang digunakan yaitu distribusi Normal untuk TBF dan distribusi Weibull untuk TTR karena memiliki nilai P-Value $>\alpha=0.01$ dan mempunyai nilai Anderson-Darling yang paling kecil[8]. Tahap selanjutnya adalah mencari parameter distribusi menggunakan software Avsim. Berdasarkan hasil parameter distribusi pada Gambar 6 dan Gambar 7, maka selanjutnya adalah membuat perhitungan MTTF dan MTTR menggunakan distribusi yang telah terpilih seperti yang ditunjukkan pada Tabel VI untuk MTTF dan Tabel VII untuk MTTR.

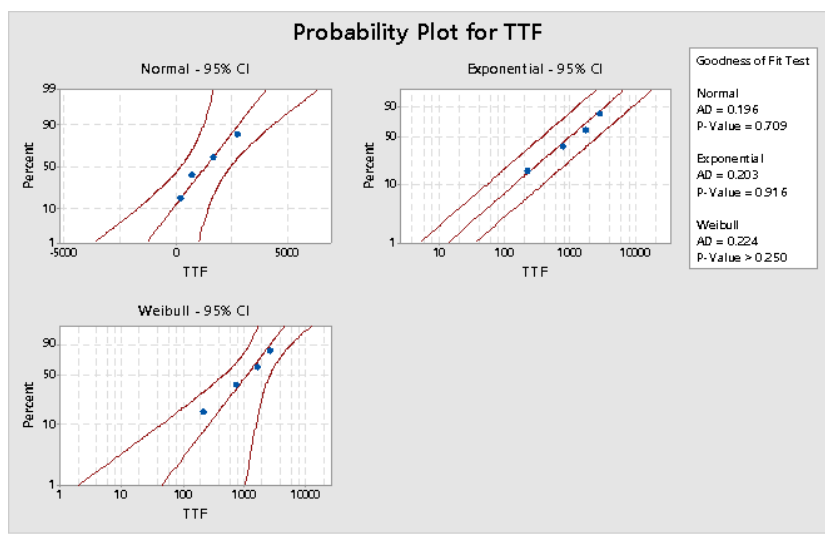

Gambar 4 Probability plot for TBF cooling system

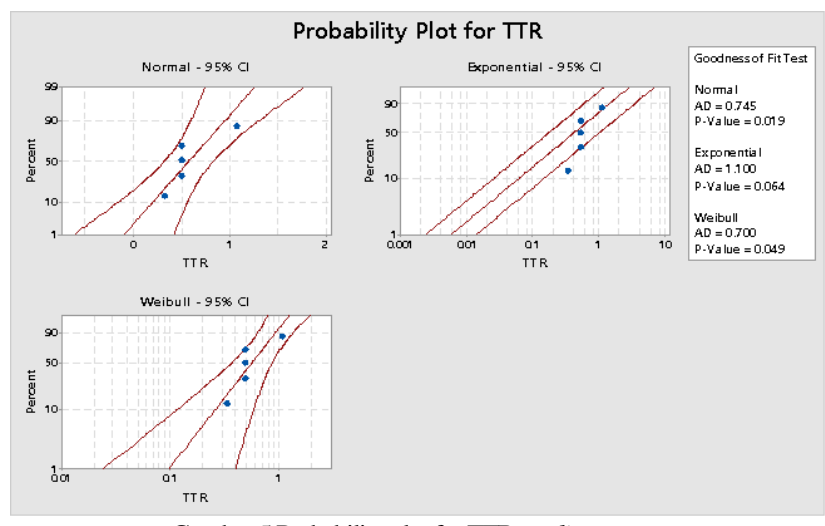

Gambar 5 Probability plot for TTR cooling system

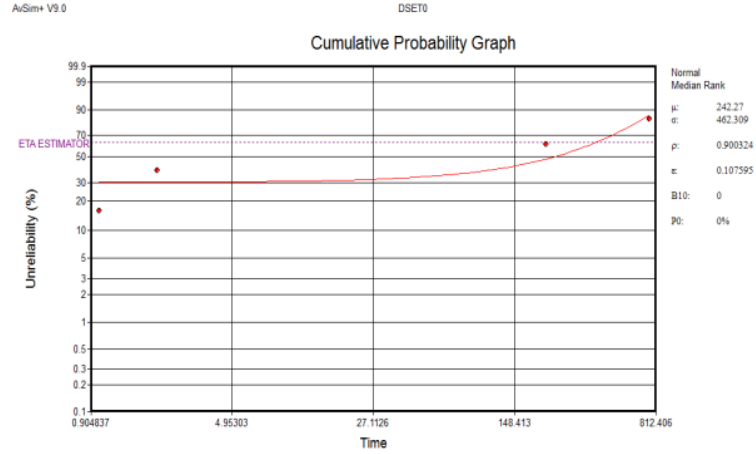

Gambar 6 Distribusi normal TBF cooling system

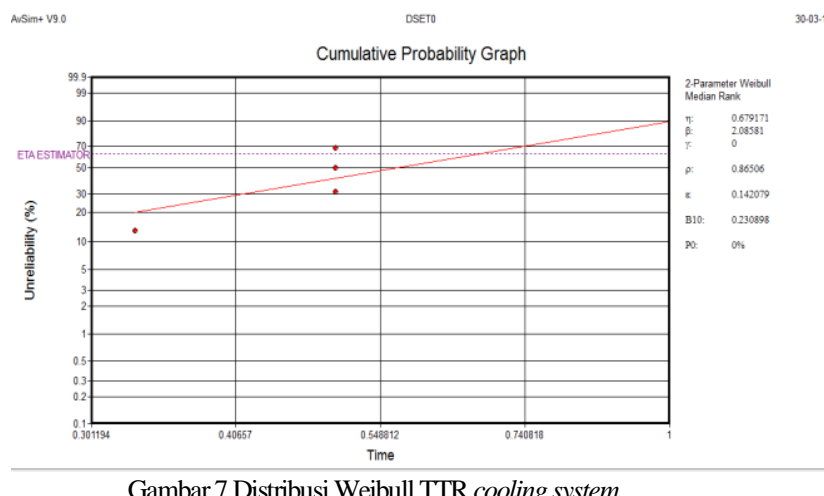

Gambar 7 Distribusi Weibull TTR cooling system

Tabel VI menampilkan hasil perhitungan MTTF komponen cooling system. Berdasarkan hasil perhitungan pada Tabel VI didapatkan nilai MTTF sebesar 242.27 jam yang berarti kemungkinan akan terjadi kerusakan berikutnya setelah 242.27 jam dari kerusakan terakhir. Tabel VII menampilkan hasil perhitungan MTTR komponen cooling system. Berdasarkan hasil perhitungan pada Tabel VII didapatkan nilai MTTR sebesar 0.60 jam yang berarti waktu perbaikan lamanya sebesar 0.60 jam. Oleh karena itu, Operator dan bagian produksi perlu mempersiapkan untuk mengantisipasi hal tersebut. Pada komponen oil system, nozzle, dan peer cara perhitungannya sama dengan komponen cooling system. Tabel VII menampilkan hasil dari perhitungan preventive maintenance.

Berdasarkan hasil perhitungan pada Tabel VIII didapatkan nilai MTTF sebesar 242.27 jam yang berarti kemungkinan akan terjadi kerusakan berikutnya setelah 242.27 jam dari kerusakan terakhir. Sedangkan nilai MTTR sebesar 0.60 jam yang berarti waktu perbaikan lamanya sebesar 0.60 jam. Oleh karena itu, Operator dan bagian produksi perlu mempersiapkan untuk mengantisipasi hal tersebut dengan adanya jadwal perawatan yang dilakukan berdasarkan beberapa jam sebelum terjadinya kerusakan mesin. Seperti untuk perawatan cooling system dilakukan setiap 200 jam sebelum kerusakan selanjutnya. Pada oil system untuk waktu penggantian oli hidrolik dilakukan setiap 3600 jam dan pengurasan oli hidrolik dilakukan setiap tahun berdasarkan ketentuan dari perusahaan. Tidak adanya jadwal pemeliharaan membuat beberapa sparepart pada mesin mengalami masalah dan akibatnya adanya waktu menunggu perbaikan sparepart mesin yang cukup lama. Oleh karena itu, perancangan jadwal pemeliharaan ini sangat bermanfaat bagi kebutuhan perusahaan untuk mengatasi waste waiting tersebut. 
TABEL VI

MTTF KOMPONEN COOLING SYSTEM MTTF (Distibusi Normal)

\begin{tabular}{ccc}
\hline & Parameter & Perhitungan \\
\hline$\mu$ & 242.27 & MTTF $=\mu$ \\
$\sigma$ & 462.309 & MTTF $=242.27$ \\
$\rho$ & 0.900324 & \\
$\varepsilon$ & 0.107595 & \\
\hline
\end{tabular}

TABEL VII

MTTR KOMPONEN COOLING SYSTEM MTTR (Distibusi Weibull)

\begin{tabular}{ccl}
\hline \multicolumn{3}{c}{ MTTR (Distibusi Weibull) } \\
\hline$\eta$ & Parameter & \multicolumn{1}{c}{ Perhitungan } \\
\hline$\eta$ & 0.679171 & MTTR $=\eta \times \Gamma(1+1 / \beta)$ \\
$\gamma$ & 2.08581 & MTTR $=0.679171 \times \Gamma$ \\
$\rho$ & 0 & $(1+(1 / 2.08581))$ \\
$\varepsilon$ & 0.86506 & MTTR $=0.679171 \times \Gamma(1.48)$ \\
\hline
\end{tabular}

TABEL VIII

HASIL PREVENTIVE MAINTENANCCE

\begin{tabular}{ccc}
\hline Komponen & MTTF $(\mathbf{j a m})$ & MTTR $(\mathbf{j a m})$ \\
\hline Cooling System & 242.27 & 0.60 \\
Oil System & 1544.69 & 2.04167 \\
Nozzle & 1575.702 & 1.165 \\
Peer & 931.667 & 1.59 \\
\hline
\end{tabular}

Gambaran jadwal pemeliharaan mesin akan ditampilkan pada Gambar 8. Pembuatan jadwal pemeliharaan ini dibuat berdasarkan hasil waktu dari preventive maintenance dan wawancara dengan bagian produksi. Jadwal pemeliharaan ini berisi tentang kapan komponen mesin injection molding dilakukan perawatan secara lebih lanjut untuk mencegah adanya kerusakan mesin secara mendadak dan mengurangi terjadinya downtime pada mesin.

\section{F. Future State}

Future State digunakan untuk menggambarkan kondisi yang akan datang setelah memberikan usulan rancangan untuk meminimasi waste waiting time. Terdapat beberapa perubahan pada lead time dari current state dan future state seperti lead time yang dihasilkan lebih singkat dari sebelumnya karena jika melakukan penerapan usulan pada permasalahan adanya waktu tunggu material di area blending diharapkan waktu tunggu tersebut yang berupa non value added time dapat dihilangkan.

Adanya usulan untuk permasalahan menunggu perbaikan sparepart mesin injection molding juga diharapkan dapat dihilangkan karena merupakan non value added time dan mengganggu berjalannya proses produksi, sehingga dengan adanya penerapan jadwal pemeliharaan mesin dapat menghilngkan adanya aktivitas tersebut. Gambaran dari future state dapat dilihat pada Gambar 9 dan Tabel IX.

\begin{tabular}{|c|c|c|c|c|c|c|c|c|c|}
\hline$<$ & CVV, GRADIEIENT & & W & I & EM & II & $\begin{array}{l}\mathrm{HA} \\
\mathrm{MC}\end{array}$ & $L L$ & IN INJECTION \\
\hline Periode & 200 jam $=3$ bulan & & & & Setiap & & & & \\
\hline Waktu & 400 jam $=6$ bulan & $\stackrel{\frac{1}{\pi}}{1}$ & & & & & & $\underset{\frac{\pi}{2}}{\frac{1}{2}}$ & \\
\hline & $1200 \mathrm{jam}=1$ tahun & $\frac{0}{a}$ & $\frac{\varepsilon}{\sigma}$ & $\underset{\sigma}{\varepsilon}$ & $\stackrel{\text { 뜌 }}{\rightarrow}$ & $\stackrel{\frac{\pi}{0}}{\stackrel{5}{n}}$ &. & $\stackrel{\pi}{2}$ & Keterangan \\
\hline & $3600 \mathrm{jam}=3$ tahun & 京 & $\overline{\mathrm{o}}$ & চ্े & ذ્તે & 品 & & & \\
\hline & 1. Periksa level / ketinggian air radiator & & & & & & & & \\
\hline Cooling & 2. Periksa kejernihan air radiator & & & & & & & & \\
\hline System & 3. Bersihkan radiator dan air radiator & & & & & & & & \\
\hline & 4. Perawatan cooling system & & & & & & & & \\
\hline & 5. Periksa level / ketinggian oli mesin & & & & & & & & \\
\hline Oil & 6. Penggantian oli Hidrolik & & & & & & & & \\
\hline Surtem & 7. Penggantian oli Sleading & & & & & & & & \\
\hline & 8. Pengurasan oli Hidrolik & & & & & & & & \\
\hline & 9. Perawatan oli samping & & & & & & & & \\
\hline & 10. Periksa nozzle dalam mesin & & & & & & & & \\
\hline Nozzle & 11. Periksa injektor nozzle & & & & & & & & \\
\hline & 12. Tune up nozzle & & & & & & & & \\
\hline Peer & 13. Periksa keadaan peer & & & & & & & & \\
\hline & 14. Penggantian peer & & & & & & & & \\
\hline & 15. ............................ & & & & & & & & \\
\hline Lain-lain & 16. ........................ & & & & & & & & \\
\hline & 17. .............................. & & & & & & & & \\
\hline & Dibuat oleh, & & & & & & & & wab, \\
\hline & & & & & & & & & \\
\hline & & & & & & & & & \\
\hline & & & & & & & & & \\
\hline
\end{tabular}


TABEL IX

HASIL PROCESS ACTIVITY MAPPING (FUTURE STATE)

\begin{tabular}{lc}
\hline \multicolumn{1}{c}{ Keterangan } & Waktu (detik) \\
\hline Lead Time & 5951.66 \\
Total Value Added Time & 1111.85 \\
$\%$ Value Added & 18.7 \\
Total Necessary Non-Value Added Time & 4121.05 \\
$\%$ Necessary Non-Value Added Time & 69.2 \\
Total Non Value Added Time & 721.87 \\
$\%$ Non Value Added Time & 12.1 \\
\hline
\end{tabular}

\section{KESIMPULAN}

Pada hasil penelitian yang telah dilakukan untuk mendukung tugas akhir ini, didapatkan beberapa kesimpulan yaitu sebagai berikut:

A. Adanya penyebab terjadinya waste waiting time yang terjadi pada proses produksi spring guide $X X X$ disebabkan oleh faktor metode dan faktor mesin yang permasalahan dan akar penyebabnya adalah sebagai berikut:

1. Faktor Metode

Permasalahan 1: Adanya waktu tunggu material di area blending

Akar Penyebab 1: Tidak ada tindakan preventive maintenance oleh perusahaan

\section{Faktor Mesin}

Permasalahan 2: Menunggu perbaikan sparepart mesin injection molding

Akar Penyebab 2: Tidak ada jadwal pemeliharaan peer, cooling system, nozzle, dan oil system secara rutin

B. Adanya usulan rancangan untuk meminimalisir waiting time pada proses produksi spring guide $X X X$ yang disebabkan oleh akar penyebab yaitu sebagai berikut:

1. Usulan rancangan untuk meminimasi tidak adanya tindakan preventive maintenance oleh perusahaan yaitu dengan pembuatan interval waktu pemeliharaan mesin injection molding selanjutnya dengan preventive maintenance.

2. Usulan rancangan untuk meminimalisir akar penyebab tidak adanya jadwal pemeliharaan peer, cooling system, nozzle, dan oil system secara rutin adalah dengan pembuatan jadwal pemeliharaan pada sparepart mesin injection molding dan pembuatan prosedur pemeliharaan mesin injection molding. Jadwal Pemeliharaan ini menjadi usulan utama dalam meminimasi waste waiting time karena perusahaan belum mempunyai jadwal pemeliharaan untuk mesin injection molding.

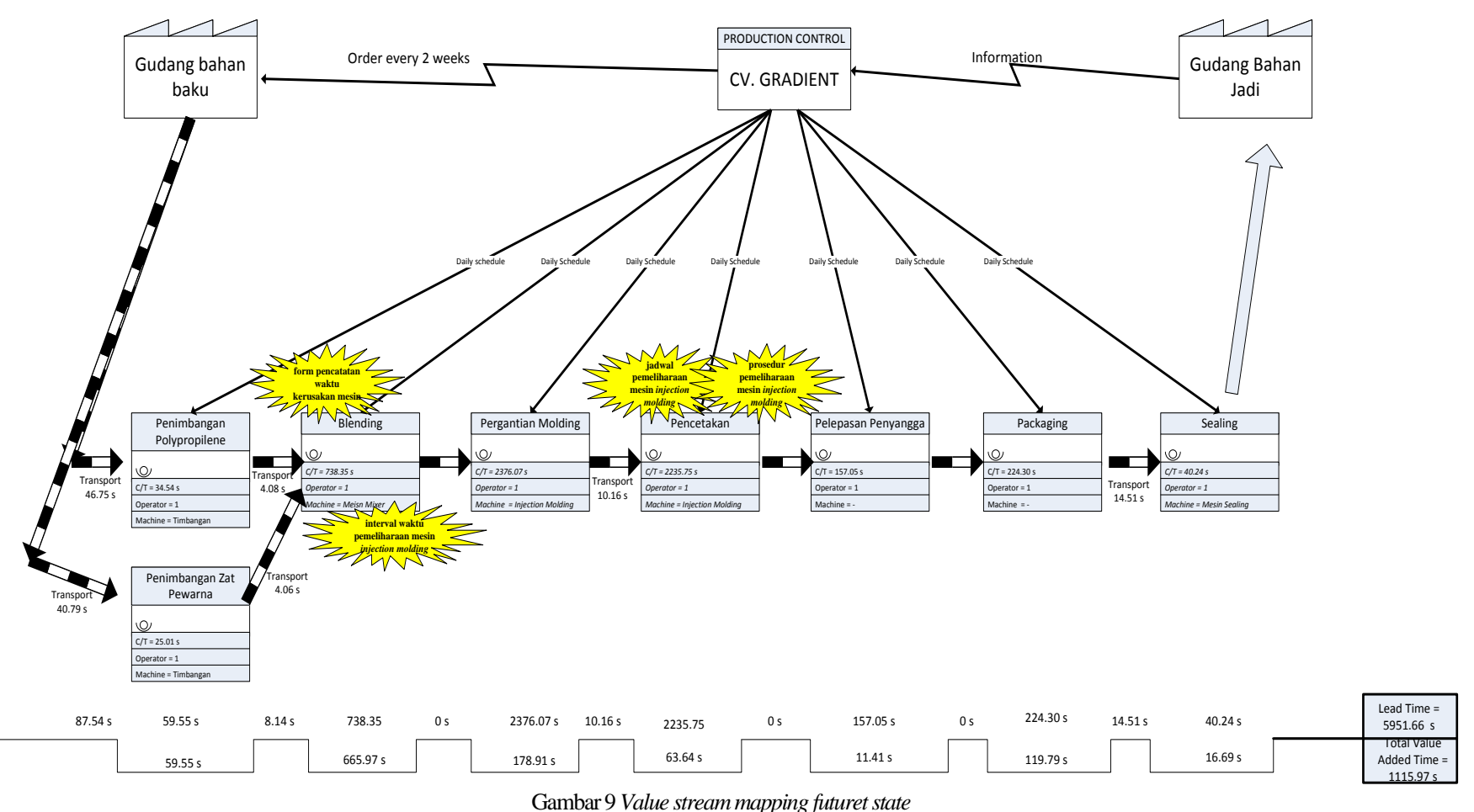

\section{DAFTAR PUSTAKA}

[1] Farah Widyan H, Putu Dana K, and Hari Supriyanto, "Penerapan Lean Manufacturing untuk Mereduksi Waste di PT. ARISU", Jurnal Teknik ITS, vol. 1, no. 1, ISSN: 2301-9271, pp. 135-140, 2012.
[2] Gasperz, V., \& Fontana, A. (2011). Lean Six Sigma for Manufacturing and Service Industries. Bogor: Vinchristo Publication.

[3] Muhammad Shodiq Abdul K and Haryono, "Analisis Penerapan Lean Manufacturing untuk Menghilangkan 
Pemborosan di Lini Produksi PT Adi Satria Abadi”, Jurnal Rekayasa Sistem Industri, vol. 4, no. 1, 2015.

[4] Vanany, I. (2005). Aplikasi Pemetaan Aliran Nilai di Industri Kemasan Semen. Institut Teknologi Sepuluh, November.

[5] Kusuma, Q. (2016). Rancangan Perbaikan pada Proses Produksi Rubber Step Aspira Belakang untuk Meminimasi Waiting Time dengan Pendekatan Lean Manufacturing. Telkom University.

[6] Mohsen Alardhi, Roger G. Hannam, Ashraf W. Labib, (2007) "Preventive maintenance scheduling for multicogeneration plants with production constraints", Journal of Quality in Maintenance Engineering, Vol. 13, Issue: 3, pp.276-292.

[7] C. Richard Cassady and Erhan Kutanoglu, "Integrating Preventive Maintenance Planning and Production Scheduling for a Single Machine", IEEE Trans. On Reliability, vol. 54, no. 2, pp. 304-309, 2005.

[8] Ebeling, Charles E. (1997), An Introduction to Reliability and Maintainability. Engineering, Me Graw Hill Book Co., Singapore. 